\title{
Karst Geoheritage of Tara National Park (Serbia) and Its Geotouristic Potential
}

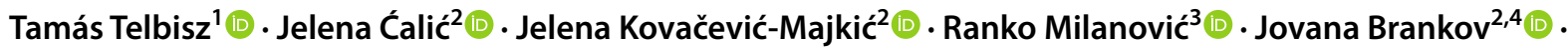 \\ Jasna Micić ${ }^{2}$ (D)
}

Received: 26 April 2021 / Accepted: 17 September 2021 / Published online: 6 October 2021

(c) The Author(s) 2021, corrected publication 2022

\begin{abstract}
By the example of Tara National Park (NP), we present how the geoheritage can and should be presented in a NP where the primary role is played by biology. Tara NP has a rich geoheritage, especially its karst phenomena, which include gorges (e.g. the 1000-m-deep Drina Gorge), plateaus with dolines, dry valleys, and uvalas as well as springs and travertines. In addition, ophiolites also enrich the geoheritage; hence, the area has a high geodiversity. Large reservoirs of the territory provide an opportunity to study the anthropogenic impact on hydrology and geomorphology. After presenting the geoheritage elements of the area, we examine the views and knowledge of local people and visitors about karst and geotourism with the help of a questionnaire survey. The results show that local residents support the further development of tourism, but geotourism is a rather new concept for them. On the contrary, tourists are more familiar with geotourism. Among the development perspectives, tourists support those that involve only minor environmental changes, that is in agreement with NP policy. Finally, we formulate some suggestions about geotourism development in the area. First, we outline some plans for new geo-educational trails and viewpoints. Second, we highlight the possibility to increase the geo-content of some already existing programs (e.g. boat tours). Third, we emphasize that geotourism of Tara should be connected to neighbouring areas. A new geopark is already under planning, which would include the area of Tara NP as well.
\end{abstract}

Keywords Doline · Gorge · Ophiolite · Questionnaire survey · Drina River

Tamás Telbisz

tamas.telbisz@ttk.elte.hu

Jelena Ćalić

j.calic@gi.sanu.ac.rs

Jelena Kovačević-Majkić

j.kovacevic@gi.sanu.ac.rs

Ranko Milanović

ranko.milanovic@nptara.rs

Jovana Brankov

j.brankov@gi.sanu.ac.rs

Jasna Micić

j.micic@gi.sanu.ac.rs

1 Department of Physical Geography, Eötvös Loránd University, Budapest, Hungary

2 Geographical Institute "Jovan Cvijić" of the Serbian Academy of Sciences and Arts, Belgrade, Serbia

3 PE “Tara National Park", Bajina Basta, Serbia

4 Institute of Sports, Tourism and Service, South Ural State University, Chelyabinsk, Russia

\section{Introduction}

Tara National Park (NP) in western Serbia was established in 1981. The most important aspect of the designation was that there are few settlements in the area, which is largely made up of karst plateaus, mostly covered by mixed forest (PicetoAbieti-Fagetum association is dominant), with high biodiversity and many endemic species. Among the forest species, the endemic and relict Serbian (Pančić) spruce (Picea Omorika) is the most special, which was described from here (Pančić 1876; Blagojević 2012). Due to its symbolic value, the brown bear (Ursus arctos) is the best known of the fauna, with the largest Serbian population living here, but there are also many less spectacular species, which are particularly valuable from a biological point of view (Radović et al. 2005). At the same time, the geoheritage of the area is also rich in significant values, the most important of which, but by no means exclusive, are the forms and phenomena related to karstification (Zeremski 1956; Milić 1980; Radović et al. 2005; Blagojević 2012). The viewpoints, which are by their 
very nature geomorphologic objects, are the most popular localities in the NP. However, the presentation of the geoheritage has so far received relatively little attention in the NP. From the point of view of geotourism, it is important to mention that the majority of tourists are domestic visitors and they come here primarily for recreational purposes, to relax and play sports (Kostić et al. 2018; Brankov et al. 2019; Telbisz et al. 2020a, b). In addition to biological and geoheritage, cultural heritage is not negligible either. There are also many archaeological sites and monuments in the area. The necropolises with stećci (characteristic Medieval tombstones) in Perućac and Rastište are part of the crossborder UNESCO World Heritage Sites since 2016. The Rača monastery was founded by the Serbian king Stefan Dragutin Nemanjić in the thirteenth century.

Therefore, starting from the above situation, our general question is how the geoheritage can and should be communicated in a NP where the primary role is played by biological values. The experts have already stated in many cases that the protection of geoheritage and geodiversity is generally given less attention than the preservation of biological heritage (Brilha 2002; Crofts 2018; Gordon et al. 2018). We do not dispute the importance and primary role of biological value protection in connection with the Tara $\mathrm{NP}$, but we would like to highlight the fact that it is important to simultaneously emphasize the geoheritage in the Tara NP, and we believe this could also be useful for geotourism. Furthermore, we would like to draw the attention of international experts interested in geoheritage to the significant geodiversity of this area. We also note that biodiversity is also partly related to karsts, which was also investigated in the framework of the EcoKarst project because Tara NP was one of the sample areas of this project (Arany et al. 2018).

Serbia currently has one geopark (Djerdap), which is also quite recent, as it was inscribed on the UNESCO Global Geopark list in 2020. Nevertheless, Serbia has a truly diverse geoheritage, which has already been reported in several studies, and among which karst objects are also significant (Tomić and Božić 2014; Maran Stevanović 2015, Božić and Tomić 2015; Tomić et al. 2019, 2020; Antić et al. 2020a, b; Petrović et al. 2020). However, no international publication has yet been published on the geoheritage of Tara NP. The fact that 2021 is the International Year of Caves and Karst (IYCK) adds to the actuality of the presentation of karst geoheritage.

Specifically, the objectives of this study are:

1) To present the diverse karst morphology and karst hydrological processes characteristic of the studied area.

2) To present the specialty of the geoheritage of the area. In fact, this is a transitional zone, as the area is part of the inner Dinarides mountain range; therefore, it is lithologically more diverse than the central parts of the
Dinarides. Several phases of the transition between the former oceanic crust as well as the carbonate platforms can be well observed in the study area, which also makes it possible to tell a well-constructed "geo-story".

3) Examine the awareness of the local population and visitors about geotourism and karst. This was examined in the framework of a more comprehensive survey, while the related results are presented here.

4) We make some suggestions on how the presentation of the geoheritage in the Tara NP could be made more colourful and how geotourism could be promoted more widely in the study area.

\section{Methodology}

The basis for presenting the geoheritage of Tara NP is the field experience gained during the field trips carried out by the authors on the site, and more specifically, one of the authors (RM) works at Tara NP.

GIS-based morphometric analyses were also performed for some elements of the karst morphology, based on which the forms of the area can be compared with similar forms in other karst regions. For these analyses, we used 1:25,000 scale topographic maps for the area, 1:100,000 scale geological maps, and digital terrain models (DTM) as basic data. We used the SRTM database (Rabus et al. 2003) and a DTM made by digitizing topographic maps and applying kriging interpolation. Analyses were performed using ArcMap 10.3 software. Regarding the morphometric analysis of dolines, we used the methods described in Telbisz et al. (2007, 2015, 2016), and for gorges, the method presented in Telbisz et al. (2019). Doline morphometry was completed by a validation field survey, during which the dimensions of 70 dolines in three selected sample areas were measured by GPS.

Questionnaire surveys are often used to learn about the attitudes and motivations of local residents and visitors to protected areas. Previously, the focus of these studies was primarily on national parks (Trakolis 2001; Telbisz et al. 2020a, b; Nestorová Dická et al. 2020), but more recently, many of the geoheritage sites have also been studied using this method (Kim et al. 2008, Zgłobicki and BaranZgłobicka 2013, Allan et al. 2015, Božić and Tomić 2015, Štrba 2019). In some research, web-based surveys are used (Pietrzyk-Kaszyńska et al. 2012, Zgłobicki and BaranZgłobicka 2013), but on-site surveys are somewhat more common. Thus, in our research, in order to examine the attitudes of the community and visitors, multiple modes of survey research were applied as a methodological procedure. The field survey was conducted from March 2019 to January 2021 among the local community members and visitors. A sample of 405 responses was collected (197 locals and 208 visitors). The questionnaires were self-administrated, 
while for a specific segment of the population (older people, not familiar with this approach), it was necessary to use a face-to-face questionnaire. The questionnaires were delivered personally to local households, where they were filled out by one family member. The survey covered the town of Bajina Bašta, the centre and the largest settlement in the municipality, and also home of the NP headquarters, as well as different villages within the NP or its closest protection zone. As for the visitors, the location of the mass survey was the Tourist Information Centre in Mitrovac, where they were asked by NP staff to participate in the research and complete the questionnaire independently. About one-third of tourist questionnaires were completed using a web survey.

The questionnaire for locals comprised different sections-socio-demographic characteristics, opinions on the economic situation, tourism, and relation to NP. Visitors were asked for basic demographic data, as well as for the type and motive of the visit and potential development directions of the NP. Specific segments of both questionnaires, used in this paper, were dedicated to the residents' and visitors' knowledge about the karst and geotourism and were compiled of closed-ended and open-ended questions.

In addition, we conducted interviews with some key actors (NP experts, local stakeholders), the views of whichindirectly - were also included in our conclusions. The semistructured interviews were conducted in 2019, and a total of 15 interviews were collected. The interviews comprised different categories of questions related to the NP (development directions, conservation and protection, research and education, tourism, and community issues), while a specific segment covered karst geoheritage topic.

\section{Study Area}

Tara NP is located in western Serbia, along the border with Bosnia and Herzegovina (Fig. 1). The boundary of the state and the NP coincides for a section and aligns with the Drina River. The boundary of the NP to the southeast does not coincide with the natural boundaries (topography, geology), so the study area is slightly increased when karst morphology is presented. In addition, the rocks originating from the former oceanic crust and mantle are mostly located south-east from the NP area, but they are also included in the characterization of the geoheritage. We also mention that south-east of the Tara NP, there are further protected areas in the continuation of each other, these are the Šargan-Mokra Gora and the Zlatibor Nature Parks, which were established much later (in 2005 and 2017, respectively) than Tara NP. In these cases, besides the bio- and geoheritage, the purpose of intensifying and regulating the already existing tourism also played a significant role (Telbisz et al. 2020a, b).

From the orographical and geological point of view, Tara Mt. belongs to the internal range of the Dinarides, tectonically following their typical NW-SE strike. It is a lithologically complex area (Fig. 2), which was evolving dominantly within the Tethys (Neotethys) oceanic realm during the Mesozoic era (Stampfli 2000; Schmid et al. 2008; Cvetković et al. 2016, 2019; Channell and Kozur 1997; Robertson et al. 2009). The Triassic was characterised by the formation of vast carbonate platforms in a broader area, as the pre-cursors of limestone diagenesis.

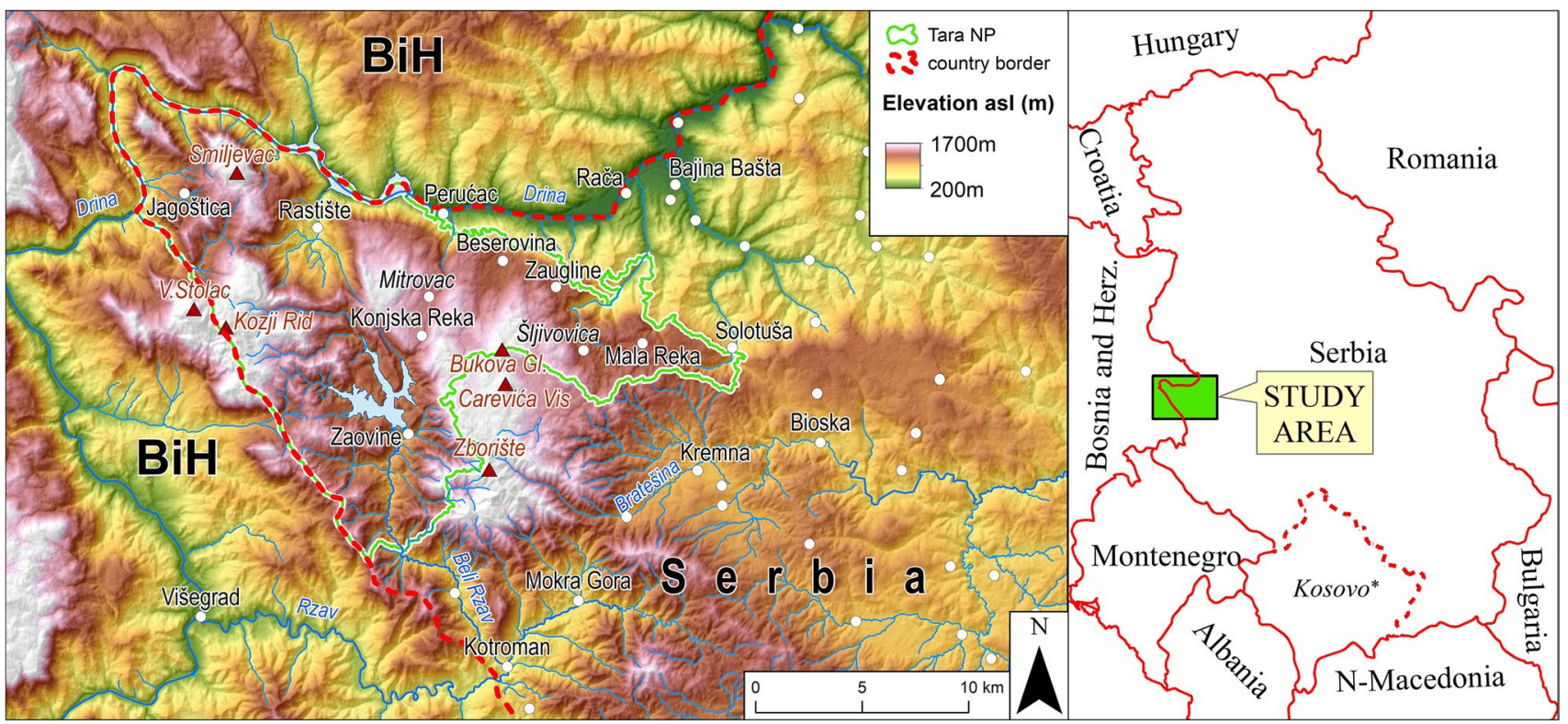

Fig. 1 Topographic map of Tara NP and location of the study area within Serbia. BiH: Bosnia and Herzegovina (*UN Resolution 1244) 


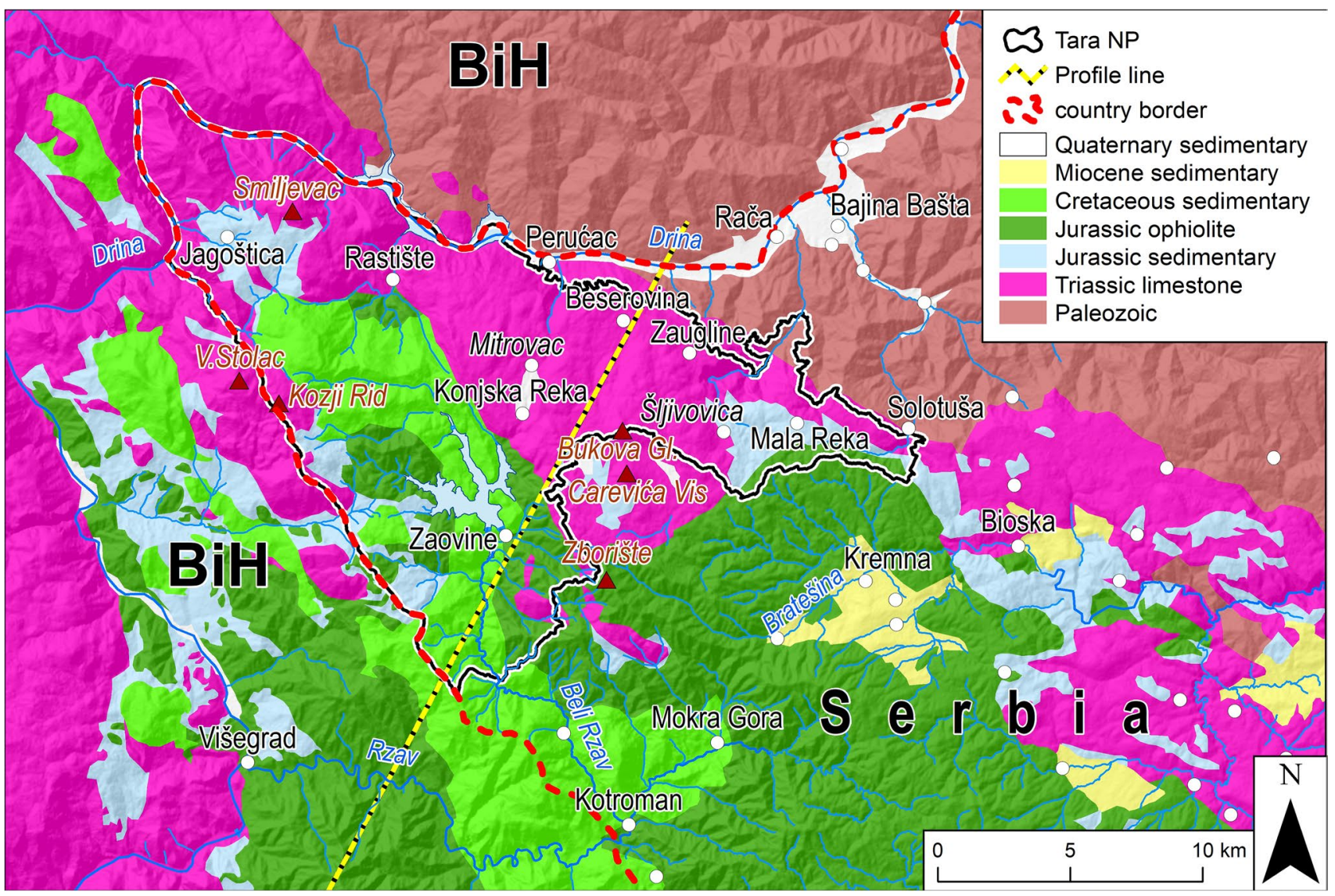

Fig. 2 Simplified geologic map of the study area (after Mojsilović et al. 1978; Olujić and Karović 1986)

On the other hand, the end of the Jurassic period brought utterly intensive submarine tectonics, resulting in the present remnants of Jurassic oceanic lithosphere fragments obducted onto continental crust, thus forming various ophiolitic assemblages containing peridotites, gabbrodiabase, harzburgites, and ophiolitic mélange. The Cretaceous period in the studied area was characterized by basinal sedimentation, forming overstep sequence made up of micritic carbonates, accompanied by marls, shales, and other non-carbonate sediments. In about $2 / 3$ of the NP area (northern and eastern parts), the Triassic rocks are dominant, while a mixture of ophiolites and Cretaceous sediments is found in the southern $1 / 3$, although Triassic limestone also outcrops here in smaller patches, as olistolithic blocks inside the ophiolitic mélange. Tara is generally an antiform structure fractured by faults with an axis along Drina River Valley (Fig. 3). Jurassic silicate sediments have remained in the large topographic depressions

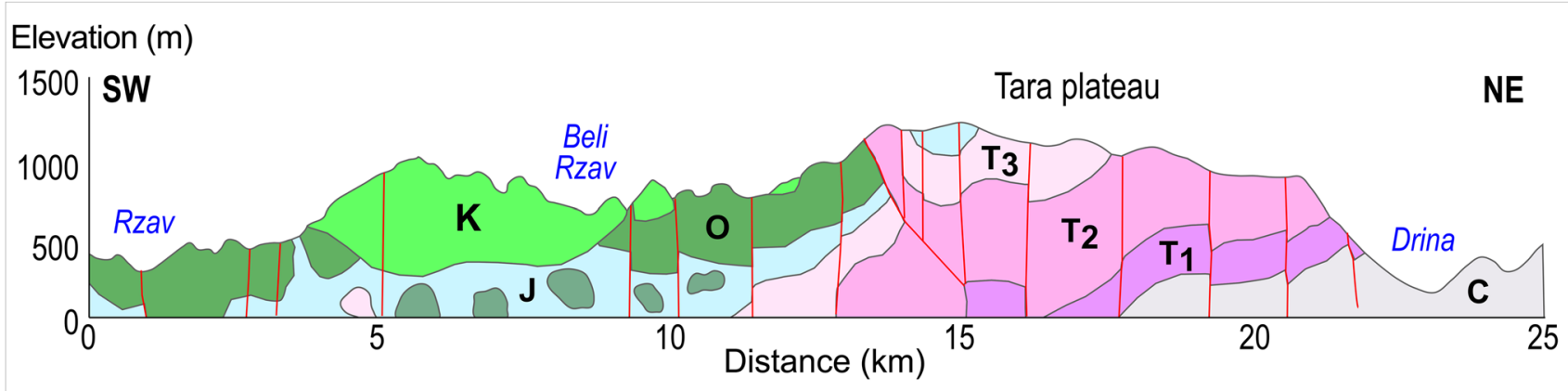

Fig. 3 SW-NE geological cross-section. For cross-section location, see Fig. 2 (after Olujić and Karović 1986) 
of the Triassic limestone plateaus in some places, while Cretaceous sediments lie at the same elevation as the plateaus in the southwestern parts. The deep incision of the Drina Gorge in the northern parts reveals a thick sequence of Triassic strata. To the northeast of the NP, there are Palaeozoic sediments (sandstone and conglomerate) and metamorphic rocks (slate, marble). To the east, the Triassic limestone belt continues, but it is already a lower, hilly area. To the south and south-east, the ophiolithic zone is predominant, occasionally intersected by smaller patches of Miocene sedimentary rocks (marl, dolomite, conglomerate, sandstone), and to the south by an intervening Cretaceous sedimentary strip. From a hydrogeological point of view, Triassic limestones are well karstified, the jointed Jurassic rocks can be considered semi-permeable, while Palaeozoic shales at the base function as impermeable rocks (Ristić Vakanjac et al. 2015).

The above geological picture is largely reflected in the topographic features as well. Considering the location of the geological, topographic, and karstic forms, we can distinguish three large units in the NP area. The north-western unit is Zvijezda, which rises to $1445 \mathrm{~m}$ (Smiljevac peak), the largest is the Tara plateau, which is slightly lower at its highest point (Carevića Vis, $1426 \mathrm{~m}$ ) than the previous one. The south-eastern unit is Zaovine: here is the highest peak in the Serbian part (Kozji Rid, 1591 m). If we consider a broader area, the peak Veliki Stolac on the other side of the border (in Bosnia and Herzegovina) is the highest point at $1675 \mathrm{~m}$ above sea level. Each of these peaks is made up of Triassic limestone. As for their relief, Tara is a slightly dissected plateau, which can be explained by the dominance of karstic rocks. Zvijezda is also largely composed of Triassic limestone, but here Jurassic silicate rocks also represent a significant part, and the density of structural lines is high, which allowed the formation of a well-developed surface water network and the strong dissection of the surface. The Zaovine area, made up of ophiolites and Cretaceous sedimentary rocks, is fluvially the most dissected.

The present surface hydrographic network of the area can be distributed into three watersheds: the direct Drina River watershed, the Beli Rzav River watershed (which is a tributary system of Drina), and the Bratešina River watershed towards the east. The watercourses of Tara Mountain are fast, clear, and cold. Permanent watercourses have high gradients, especially those on the northern and western hillslopes. In some parts, they cut deep gorges and canyons. Waterfalls are characteristic of almost all high gradient watercourses. Periodic watercourses are characteristic of the karstic Tara plateau. Their riverbeds are dry during the summer. Some streams end in sinkholes.

\section{Results}

\section{Karst Morphology}

First, we examine the small-scale karstic forms, i.e. the karren. As the area is basically mid-mountainous and densely covered with forests (80\%), its soil cover is also developed, so we can mostly find subsoil karren, which can only be observed, where they are partially exhumed, or in road cuts (Fig. 4). Bare karren are found mainly along the steep gorge hillslopes, which are usually difficult to access. The structural effect, the linear, and rectangular features preformed by joints are characteristic for most karren; thus, kluftkarren (grikes) and rundkarren (rounded karren) can be considered as the most common types.

The diagnostic karst landforms are the dolines (Ford and Williams 1989). These are abundant in the study area. Based on topographic maps at a scale of $1: 25,000$, there
Fig. 4 Left, exhuming subsoil karren; right, structurally guided karren at the Tara plateau edge (photos by Telbisz)
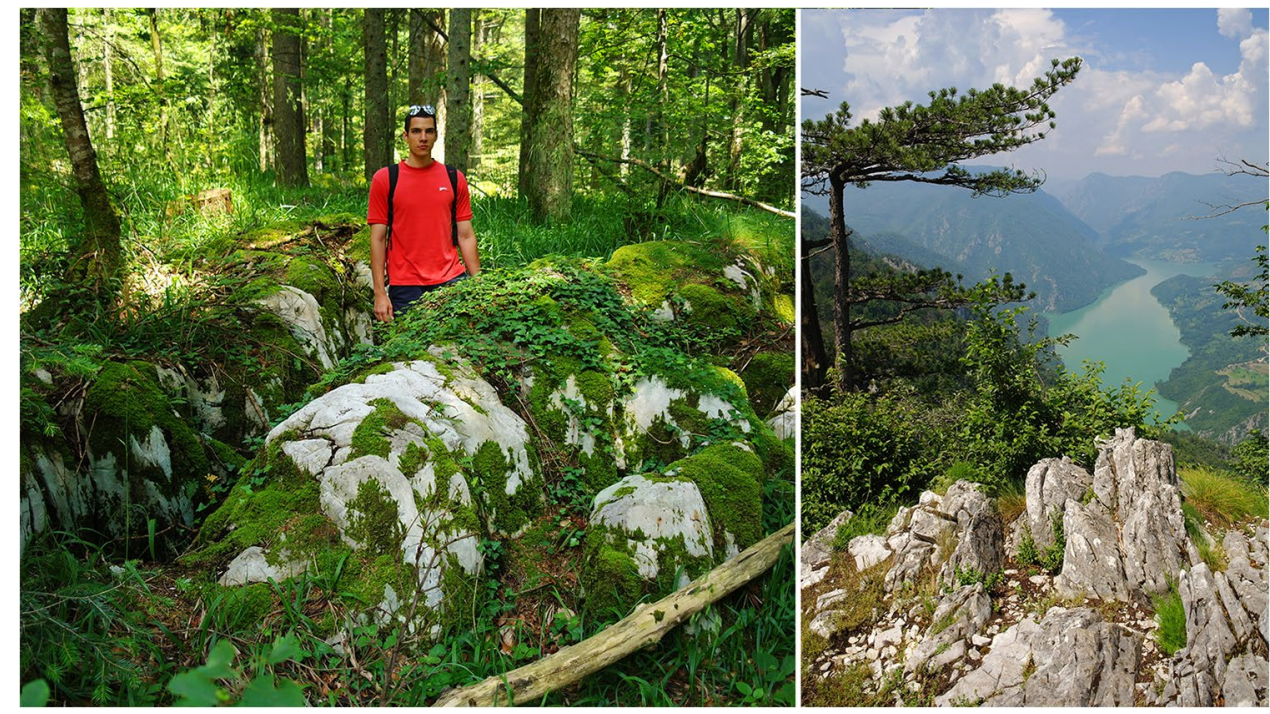
Fig. 5 Karst landforms in the study area. Numbers 1-4 mark the locations of the planned thematic paths. Letters refer to gorges, BR, Beli Rzav; B, Brusnički Potok; De, Derventa; D, Dolovi; M, Matića Potok (Selski Potok, Zvijezda Canyon); N, Neveljski Potok; R, Rača

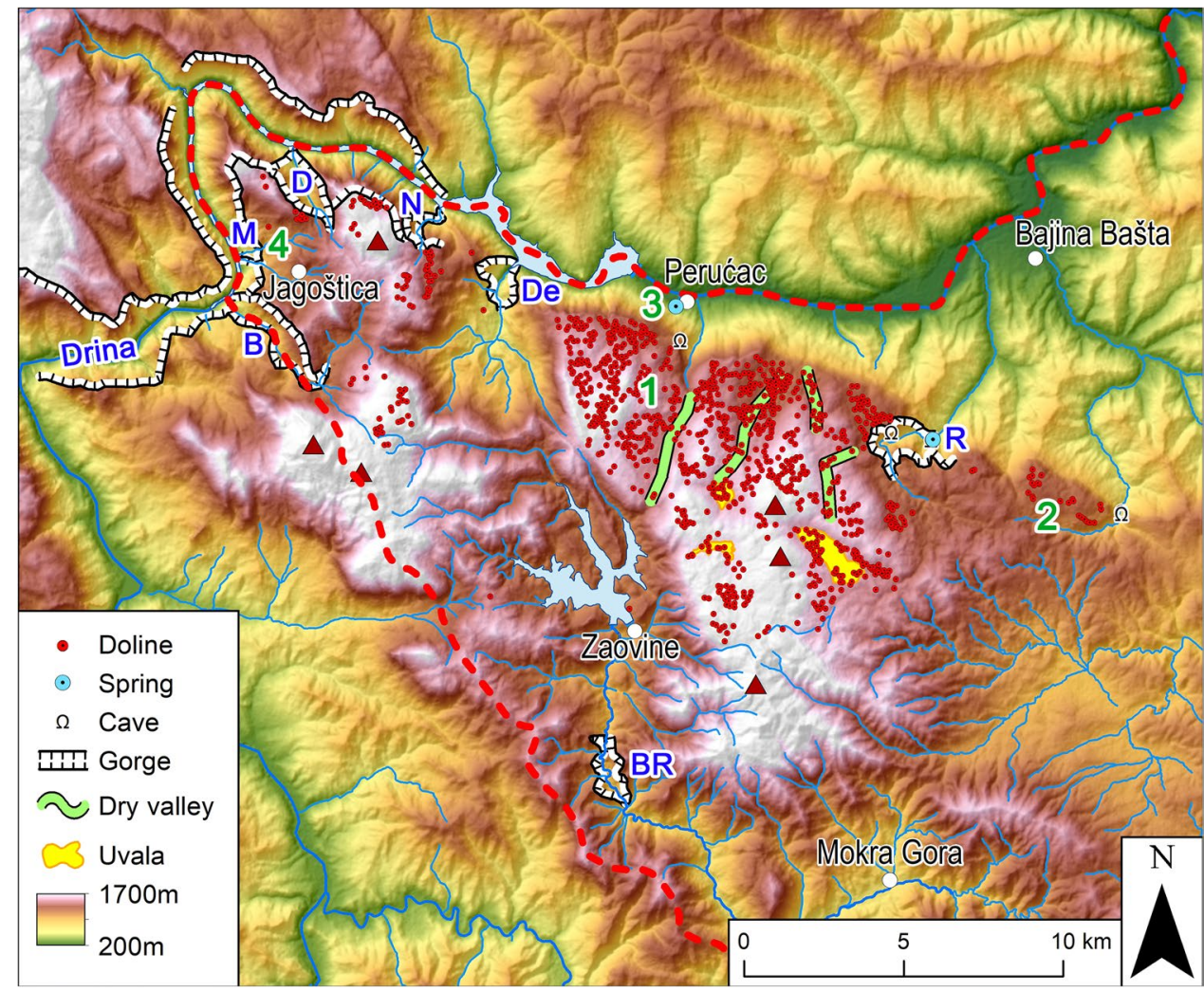

are 1025 dolines in the study area (Fig. 5). At this scale, smaller forms do not appear in the map, so this number can be considered a lower estimate. Based on our field survey, which covered a total of 70 dolines in three sample areas, we found that the number of these landforms in the field was on average 1.7 times higher than in the map. Examining their spatial distribution, we can state that based on the topographic map, $91 \%$ (i.e. 928) of the dolines are located on the Tara Plateau, which is the most suitable for the development of the dolines both for lithological and topographic reasons. The Zvijezda area is lithologically partly suitable, but due to its strong topographic dissection presented above, the number of dolines is not too large here (66), whereas in the Zaovine unit, the surface proportion of karstifiable rocks is subordinated; consequently the number of sinkholes is small, only 31 . Accordingly, the values of doline density were determined, for which only the terrain suitable for doline evolution, i.e. with an average slope of less than $20^{\circ}$, was taken into account. Based on this, the following doline density values were obtained: $9.4 \mathrm{dol} / \mathrm{km}^{2}$ for Tara, $2.6 \mathrm{dol} / \mathrm{km}^{2}$ for Zvijezda, and $0.4 \mathrm{dol} / \mathrm{km}^{2}$ for Zaovine. The size of the dolines can be well characterized by the planform area. For the whole study territory, the planform area of the dolines varies between the extreme values of 152 and 28,115 $\mathrm{m}^{2}$. The size of a "typical doline" is better expressed by the median rather than the mean (which is strongly modified by the extreme values). The median planform area for the entire study territory is $711 \mathrm{~m}^{2}$. This provides an opportunity to compare Tara NP with other karst regions (e.g., Aggtelek Karst/Hungary, Telbisz (2001); Miroč/Serbia, Telbisz et al. (2007); Velebit/Croatia, Marković et al. (2016); Munții Pădurea Craiului/Romania, Telbisz et al. (2015); Taurus/ Turkey, Öztürk et al. (2018)). Based on this, it turns out that in the case of the Tara plateau the density is medium, and in the case of the other sub-areas the density is particularly low. The size of the dolines is also significantly smaller than, for example, in the typical mid-mountain karst areas mentioned above. The depth of the sinkholes is also an important morphometric parameter, but this cannot be determined with sufficient accuracy from topographic maps at the given scale. The location of the dolines is significantly influenced by the structural lines along which the infiltration is more intense; thus, doline initiation starts first along these lines and their evolution is also faster here. This structural preformation is well characterized by the fact that $31 \%$ of the sinkhole centres are closer than $100 \mathrm{~m}, 51 \%$ closer than $200 \mathrm{~m}$, and $67 \%$ closer than $300 \mathrm{~m}$ to a structural line.

By many authors, twin dolines consisting of a few coalesced forms are called uvalas. However, according to Ćalić's (2011) study, we do not consider these simple forms to be uvalas. Instead, uvalas are complex closed depressions, which have a larger extent (some $\mathrm{km}^{2}$ ), are usually elongated, containing dozens of smaller closed depressions (dolines). These uvalas are typically associated with more 
pronounced structural lines, and due to their uplifted position, they do not have larger, cohesive, non-karstic sedimentary fillings (but smaller fillings may occur).

Based on the topographic maps, we were able to delineate five larger depressions, which were defined by their outermost closed contour line. However, in reality, three of these depressions form a larger unit, even if the closedness of the contour lines to this larger unit is no longer satisfied. These depressions largely meet the above-mentioned uvala conditions. The largest (complex) form has an area of $1.6 \mathrm{~km}^{2}$, while the two separate depressions have 0.38 and $0.41 \mathrm{~km}^{2}$, respectively. Based on this, these forms can be considered as uvalas, although proluvial sediments and, in one case, Jurassic silicate rocks appear on their substrate, on which intermittent water cover may also form (Fig. 6). This latter hydrological property is characteristic to poljes and it means some difference compared to the definition by Ćalić (2011).

In karst areas, the valley types are specific and differ from the typical fluvial valley types. One of the characteristic valley types of karst regions are the dry valleys (Bočić et al. 2015), which are present on the extensive Tara plateau. Their directions are strongly determined by the structural lines.

Other characteristic valley forms of karst areas are gorge valleys, which may be formed by epigenetic process or cave rupture, or a combination of these (Hevesi 2000; Ouimet et al. 2008). There are several smaller gorges in the Tara NP (Fig. 7), and one dominant surface form is the gorge of the Drina River, which forms the border of the NP and also of Serbia (Fig. 8). The direction of the river at NW is sharply broken, so it borders the study area from several sides. The morphometric parameters and some characteristics of the gorges are presented in Table 1. The quantitative parameters were determined based on topographic maps and digital terrain models (SRTM). Each gorge in Tara was formed by allogenic watercourses, which have a smaller or larger nonkarstic catchment; thus, they are fluviokarst landforms. In terms of walkability (and thus tourism), each gorge falls into a different category (see Table 1). The Zvijezda Gorge is actually a canyon, explored recently by a vertical canyoning team. In the topographic maps, it is marked as Matića Potok but the local population uses the name Selski Potok. The first exploration team named it Zvijezda Canyon in order to praise the whole Zvijezda area. It is considered to be the highest gradient canyon in Serbia, thus it is of national significance. The stream profile of this gorge shows a total elevation difference of $400 \mathrm{~m}$ and is characterized by 40 waterfalls between 5 and $40 \mathrm{~m}$ in height. However, this canyon is extremely difficult to pass through, and it is located in a strictly protected part of the NP, in hard-to-reach terrain. In the steep valley sides of Drina Gorge, there may still be
Fig. 6 Large depressions on Tara Plateau. a The depression named Bare (meaning ponds in Serbian) with a mediumsized doline in the foreground. b Karajića Bara depressions with small sinkholes $(1,2)$ and a periodic stream cut into proluvial sediments (3) (Photos by Telbisz)

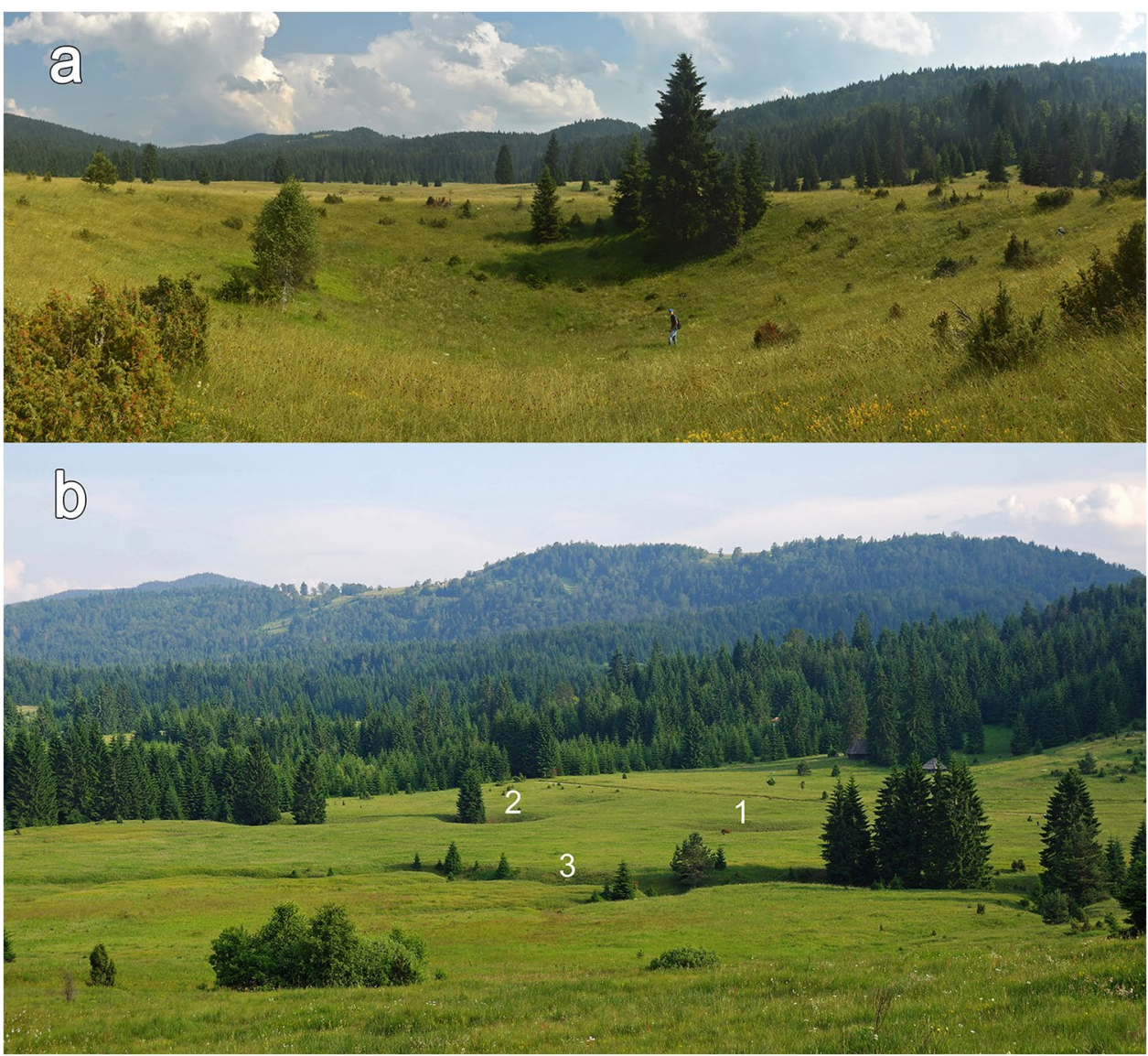


Fig. 7 Gorges in Tara NP. Left, Rača; centre, Beli Rzav; right, Matića Potok/Zvijezda (photos by Telbisz, Milanović, Vučković, respectively)

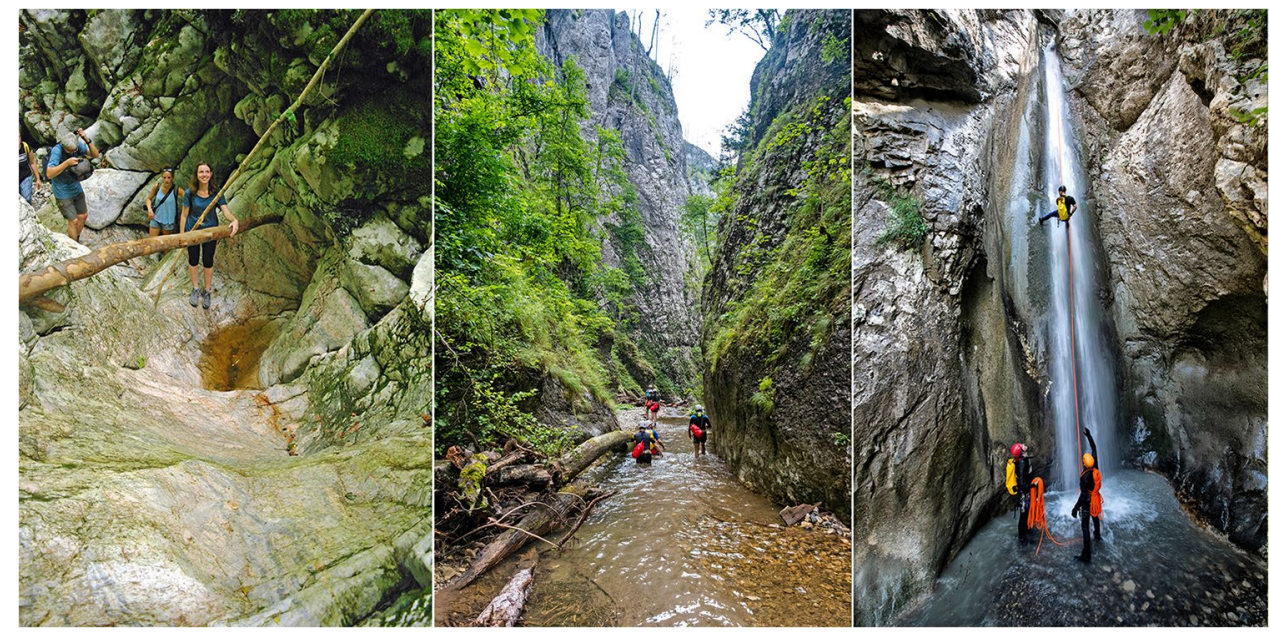

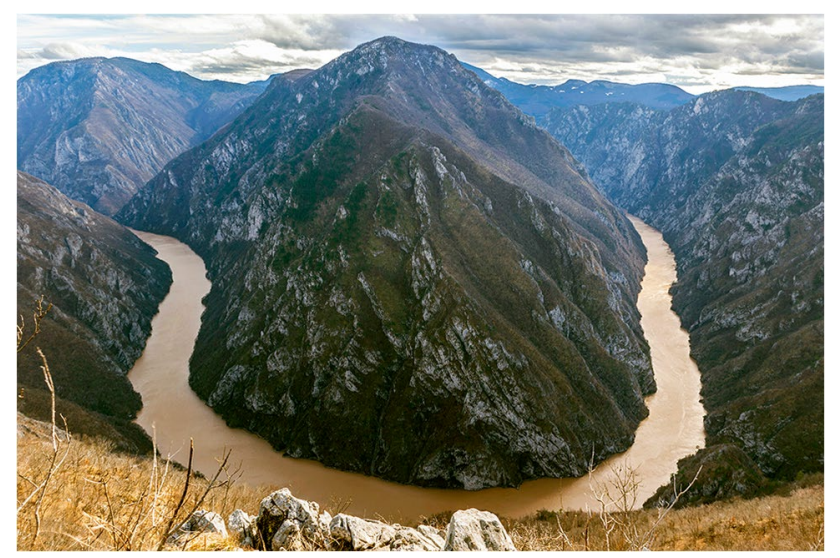

Fig. 8 Drina Gorge and Zvijezda Mountain from the Bosnia and Herzegovinan side (photo by Milanović)

some unexplored small but steep canyons. Due to its size, Drina Gorge can be considered an object of international significance. The gorge section of the river valley in this area is $25-\mathrm{km}$ long, with a maximum depth of $1040 \mathrm{~m}$, and a width of 1000 to $3500 \mathrm{~m}$. (It is interesting to note that the famous Tara River canyon in Montenegro belongs to the upstream tributary of the Drina River.) Due to the hydroelectric dam created at Perućac, there is a long reservoir lake in the gorge that makes it possible to use tourist boats in the gorge. However, as the Drina Gorge is an international boundary, it is only possible to ship here with permission. All gorges are situated in the protection zone I of the NP.

As opposed to other karst values of Tara Mt, underground karst is less remarkable and certainly less attractive for a broader public. There are approximately 90 known caves. The number depends on the criteria in the definition because some of them are less than 5-m long, rather defined as rock shelters. The caves have been explored and mapped by the Exploration club "Manda" from Valjevo during the 1960s, 1980s, and 2011-2013, as well as by Bosco (2016). A large majority is less than 100-m long and not suitable for touristic visits. In the highest parts of the morphological unit Zvijezda, the caves are predominantly vertical. The deepest one, Jama Kod Čekove Kuće, reaches $280 \mathrm{~m}$ and is extremely difficult for exploration due to very narrow passages. In the mountain slopes and foothills along the Drina River, there are hardly reachable short caves, both in the Zvijezda segment and further downstream, below the viewpoints Banjska Stena and Kozja Stena. Caves within the Rača Canyon are up to $50-\mathrm{m}$ long. Their entrance parts are at some places visible from the canyon, but the morphology inside is not appropriate for visits. Groups of small caves are also present in the easternmost part of the NP in the area of Solotuša, as well as in Račanska Šljivovica. Some of the caves are potentially interesting for geo-scientific approach (phreatic morphology high in the vadose zone, remarkable fault planes), but the most significant results have been achieved in the field of biospeleology (Stojanović et al 2014; Ćurčić et al. 2015) and this type of research will certainly proceed.

Springs and travertines also belong to the karst morphology of the area. According to the karst character, springs are rare phenomena on the Tara plateau, and their discharge is small (less than $1 \mathrm{l} / \mathrm{s}$ ). On northern escarpment towards the Drina River, the highest permanent springs occur at 700-750 m a.s.1. From that area westwards, they continuously occur along the contact with schists. Also on that north escarpment, there are high discharge karst springs outflowing from fissures. Finally, there are springs along the thalweg of valleys at the contact of karst and impermeable rocks. In the southern part of Tara, springs are numerous on serpentinites. Springs with high discharges from 100 to 300 1/s (Perućac spring, Rača spring, Ladjevac spring, and Solotuša spring) are of karstic origin. Perućac spring is the largest karstic spring in Tara Mt. with a discharge of $300 \mathrm{l} / \mathrm{s}$. It is the source of the Vrelo watercourse, which is just 365-m long and therefore named "Year River". At its mouth to the Drina River, 
Table 1 Some parameters of gorges found in Tara NP. Width is calculated between valley margins; max. depth means the elevation difference between the valley margin and the nearest valley bottom point; elevation drop is the difference in elevation between the start and end points; finally, mean gradient is the ratio of drop to length

\begin{tabular}{|c|c|c|c|c|c|c|c|}
\hline Name & Length (km) & Width $(\mathrm{km})$ & Max. depth (m) & $\begin{array}{l}\text { Elevation } \\
\text { drop }(m)\end{array}$ & $\begin{array}{l}\text { Mean } \\
\text { gradient } \\
(\mathrm{m} / \mathrm{m})\end{array}$ & Description & Tourism potential \\
\hline Beli Rzav & 2.9 & $0.2-1$ & 300 & 85 & 0.03 & $\begin{array}{l}\text { Stream valley, the } \\
\text { bottom part of slopes } \\
\text { is rocky and narrow, } \\
\text { permanent water } \\
\text { flow }\end{array}$ & Easy canyoning \\
\hline Brusnički Potok & 5.0 & $0.3-1.2$ & 530 & 690 & 0.14 & $\begin{array}{l}\text { Stream valley, the } \\
\text { bottom part of slopes } \\
\text { is rocky and narrow, } \\
\text { permanent water } \\
\text { flow }\end{array}$ & $\begin{array}{l}\text { Only with climbing } \\
\text { equipment; interna- } \\
\text { tional border }\end{array}$ \\
\hline Derventa & 1.9 & $0.2-1.3$ & 630 & 130 & 0.07 & $\begin{array}{l}\text { Stream valley, bottom } \\
\text { part of slopes is } \\
\text { rocky, permanent } \\
\text { water flow }\end{array}$ & $\begin{array}{l}\text { Passable by car; asphalt } \\
\text { road with tunnels }\end{array}$ \\
\hline Dolovi & 3.0 & $0.2-1.3$ & 600 & 730 & 0.24 & $\begin{array}{l}\text { Stream valley, bottom } \\
\text { part of slopes is } \\
\text { rocky, permanent } \\
\text { water flow }\end{array}$ & Walkable \\
\hline Drina River & 25 & $1-3.5$ & 1040 & 0 & 0.00 & $\begin{array}{l}\text { Large river valley with } \\
\text { a reservoir lake, } \\
\text { steep, rocky slopes }\end{array}$ & $\begin{array}{l}\text { International border; } \\
\text { passable by tourist } \\
\text { boats }\end{array}$ \\
\hline Matića Potok (Zvijezda) & 0.8 & 0.2 & 50 & 400 & 0.50 & $\begin{array}{l}\text { High gradient canyon } \\
\text { with waterfalls, per- } \\
\text { manent water flow }\end{array}$ & $\begin{array}{l}\text { Extreme canyoning, } \\
\text { strictly protected area }\end{array}$ \\
\hline Neveljski Potok & 2.1 & $0.2-0.7$ & 300 & 700 & 0.33 & $\begin{array}{l}\text { Wide at the upstream } \\
\text { part, narrow near } \\
\text { the mouth, hence } \\
\text { its local name Grlac } \\
\text { (="bottleneck"), per- } \\
\text { manent water flow }\end{array}$ & Easy canyoning \\
\hline Rača & 3.2 & $0.2-1.2$ & 330 & 425 & 0.13 & $\begin{array}{l}\text { Stream valley, the } \\
\text { bottom part of slopes } \\
\text { is rocky and narrow, } \\
\text { erosion potholes, } \\
\text { episodic water flow }\end{array}$ & $\begin{array}{l}\text { Equipment required } \\
\text { (ladders, ropes) to } \\
\text { make it passable; an } \\
\text { important brown bear } \\
\text { (Ursus arctos) reserve }\end{array}$ \\
\hline
\end{tabular}

it flows over travertine depositions forming a 14-m-high waterfall. Its water is used for fishponds and breeding of trouts (Salmonidae) and also for a mini hydro-power station "Vrelo". Travertines are also significant at Ladjevac spring near the Rača monastery. Most springs are easily reachable and have multiple purposes. They serve as a water source for nature lovers and researchers, as tourist targets, as curative water, etc. Some springs have hypothermal water (spring Ladjevac), while some are mineralized and have curative quality (Bele Vode). Banjsko Vrelo and a number of smaller springs are submerged due to the Perućac reservoir. Karst springs' water has good quality but can be quickly polluted; thus, springs with settlements in their catchment areas should be carefully protected. The springs have a touristic potential, and some of them are already tourist attractions. They are reachable by cycling tracks, hiking trails, or asphalt roads.

\section{Hydrology and Human Activities}

Hydrological conditions are determined by tectonic structures and lithology. The impact of tectonic structures on the complex groundwater circulation in the area of the Zaovine reservoir was researched by Jemcov and Mladenović (2017).

In the current picture and hydrological system of the landscape, large-scale water management constructions are also of decisive importance. A dam was built on the Drina in the period from 1959 to 1966 at Perućac for energy production and water management (Fig. 9). This dam swells a 52-kmlong reservoir in the above-mentioned gorge, fundamentally 
Fig. 9 Reservoirs in the study area. Perućac dam is the main scene of energy production, while Zaovine is a pumpedstorage reservoir. Cretaceous sedimentary rocks can be seen in the background mountain of Zaovine. (Photos by Telbisz)

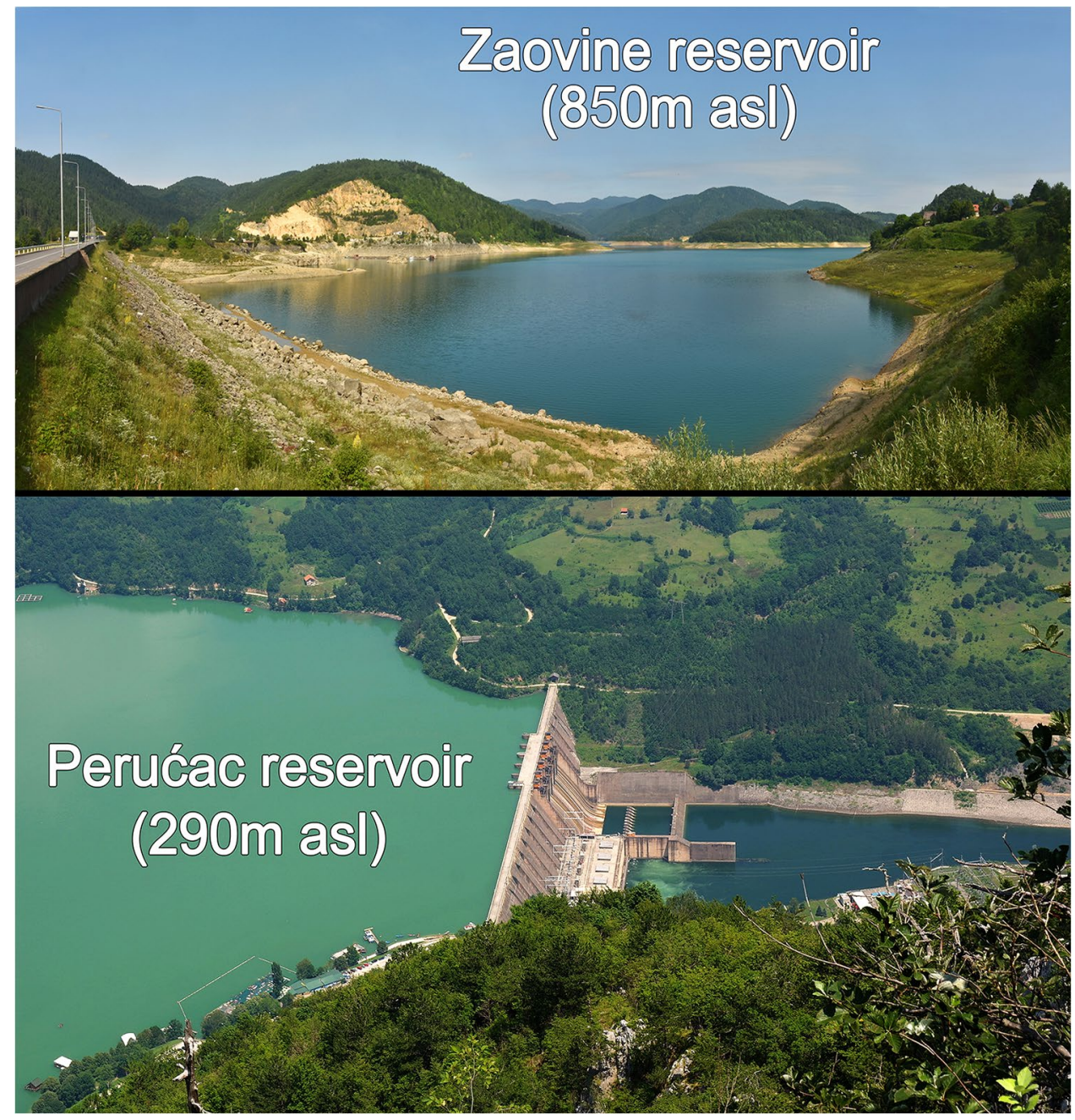

affecting the landscape and the hydrological conditions. The reservoir is multifunctional. Its main purpose is electric energy production (420 MW), but it is also used for sport and recreation (it is suitable for swimming in July-August), for fishing (14 fish species), and fish farming (there is a large trout fishpond). Water quality is in classes II and III depending on water depth and distance from the riverbanks (Kovačević-Majkić 2006). According to Serbian and similar European classifications, class I marks the highest quality, whereas class IV refers to the lowest (Official gazette SRS $5 / 68$ 1968). The efficiency of the dam operation is strongly influenced by water fluctuations; therefore, in 1983, a pumped-storage reservoir was established in the area, south of Tara Plateau. The star shape of Zaovine reservoir testifies that it was formed on a surface dissected previously by fluvial valleys. This reservoir is also multifunctional with the main function of energy production. The two reservoirs (Perućac and Zaovine) are connected by a pipe tunnel below Tara Plateau, thus allowing the operation of the pumped storage hydroelectric power plant. The water quality is high in the Zaovine reservoir, but its tourist use is constrained by significant water level oscillations. However, it is used for fishing and swimming. The reservoir can be reached by asphalt road and bicycle paths. There are also three smaller reservoirs (Spajići, Lipovica, and Crno Osoje), which are parts of the same hydro-power system. In the upper part of the Beli Rzav River watershed, the small "Kruščica" reservoir is used for water supply. The other reservoir called "Jarevac " is built for torrential flood prevention.

The fact that all reservoirs are created (at least partially) on karst areas means that water leakage must be taken into account. Jemcov and Mladenović (2017) pointed out that this process is unstoppable but could be partially controlled and slowed down. It is important because water leakage decreases the hydro-electric potential necessary for energy production. Therefore, water losses should be reduced to a minimum.

\section{Other Elements of Geoheritage}

Geodiversity of this dominantly karstic area is enhanced by the presence of "alien " lithological units—ophiolites-a 
group of various rock types originating from the Mesozoic Tethys (Neotethys) oceanic crust and upper mantle. During the subsequent phases of tectonic evolution and closure of the ocean, they were obducted on continental margins. Typical ophiolitic rocks in the wider study area, including Tara Mt. and Zlatibor Mt., are peridotite (including lherzolite and harzburgite, depending on location), gabbro-diabase, and serpentinite (Chiari et al. 2011; Robertson et al 2009; Cvetković et al. 2019; Jurković et al 2012). Within the Tara NP borders, ophiolite cross-sections may be seen on the locations Duga Kosa close to the village of Solotuša, as well as in the area of Zaovine reservoir (southern part of Krnja Jela locality). Further towards the south-east, ophiolites are present on vast areas, all the way to Zlatibor ultramafic massif. Some of the conspicuous ophiolite-related profiles on Zlatibor are present in the vicinity of Čajetina town (magnesite veins in a profile of ultramafic rocks along the main road) and on the main road Zlatibor-Nova Varoš, near the Dragalica locality.

\section{Opinion and Awareness of Local People and Visitors About Tara NP, Karst, and Geotourism}

In this article, we highlight the questions from the survey that relate to the overall perception and tasks of the NP, as well as karst and geotourism. The demographic data of the survey participants are shown in Table 2 . Slightly more than half of local respondents are men, and secondary education is the most common. In contrast, among visitor respondents, the majority is females, and those with higher education predominate. There are several reasons for such a high proportion of higher education. First, Tara hosts a large size

Table 2 Demographic data of respondents

\begin{tabular}{lllll}
\hline & \multicolumn{2}{l}{ Local People } & Visitors \\
\hline Gender & & & & \\
Male & 111 & $56.3 \%$ & 93 & $44.7 \%$ \\
Female & 86 & $43.7 \%$ & 113 & $54.3 \%$ \\
No answer & - & - & 2 & $1 \%$ \\
Age & & & & \\
$14-18$ & 17 & $8.6 \%$ & 8 & $3.8 \%$ \\
$19-30$ & 56 & $28.4 \%$ & 39 & $18.7 \%$ \\
$31-50$ & 80 & $40.6 \%$ & 132 & $63.5 \%$ \\
$51-65$ & 35 & $17.8 \%$ & 23 & $11.1 \%$ \\
Over 65 & 9 & $4.6 \%$ & 5 & $2.4 \%$ \\
No answer & - & - & 1 & $0.5 \%$ \\
Education & & & & \\
Primary school & 18 & $9.1 \%$ & 3 & $1.4 \%$ \\
Secondary school & 104 & $52.8 \%$ & 26 & $12.5 \%$ \\
Higher education & 75 & $38.1 \%$ & 177 & $85.1 \%$ \\
No answer & - & - & 2 & $1 \%$ \\
Total & 197 & $100 \%$ & 276 & $100 \%$ \\
\hline
\end{tabular}

children's camp at Mitrovac and many teachers who work there filled in the questionnaire. Second, ecotourists, geotourists, and hikers are generally more highly educated and economically stronger according to previous studies (Allan et al. 2015; Strba 2019). Third, about one-third of the questionnaires were filled online, and female respondents with higher education generally prevail in samples collected using online platforms (Brown et al. 2018).

In both groups, the middle-aged (31-50 years) class is the most common. Approximately one-third (36\%) of local respondents live in Bajina Bašta, a small town where the NP headquarters is located, and the other two-thirds live in smaller settlements.

The role of the NP was positively assessed by the majority of local residents, $17 \%$ said it was very good, and $40 \%$ said it was rather good (beneficial) for the settlement. The local residents consider tourism to be the most important of the benefits associated with the NP, followed by the mention of nature conservation, but this latter is mentioned by less people. The tasks of the NP were evaluated by the respondents on a 5-point Likert scale, based on which we calculated an average value (Fig. 10). The local residents have identified tourism as the most important task of the NP, compared to which biological conservation lags behind just a little, followed by landscape preservation and geoheritage protection. Slightly less emphasis is placed on the protection of cultural values and educational tasks, and finally, the role of scientific research is the least important according to locals. The perception of visitors is quite different in terms of the tasks of the NP. Biological preservation and landscape protection come first, followed by geoheritage protection and cultural heritage protection. This is followed by educational and scientific roles, but the latter is by no means as far behind as

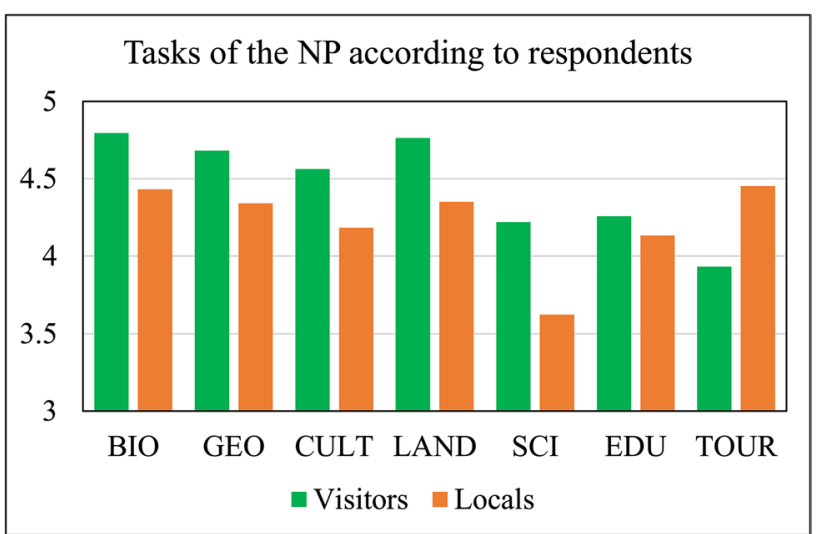

Fig. 10 Tasks of Tara NP according to local people and visitors. Respondents could evaluate each task on a 1-5 Likert-scale (1, not important; 5, the most important). This diagram presents the mean values for each task. BIO, biological protection; GEO, geological protection; CULT, cultural heritage protection; LAND, landscape protection; SCI, scientific research; EDU, education; TOUR, tourism 
in the case of the local population. Finally, tourism is the last, so visitors say it is a less important role for the NP than the other tasks mentioned earlier. At this point, therefore, the opinions of the local residents and visitors differ significantly.

One-third of the local population (36\%) is personally involved in tourism (through room rentals, shops, etc.) and a large majority (80\%) would support more tourists coming to the area. According to the current situation, the majority of tourists arriving here are domestic (this was, of course, enhanced by the COVID situation, but according to previous statistics, this statement is also true for other years, cf. Telbisz et al. 2020a, b). Visitors typically arrive here for 2-4 days, for a family trip, and stay at private accommodation. An important aspect is that in our survey, $81 \%$ of the visitors were returning tourists, and half of the latter had already visited Tara NP at least five times. The majority of respondents $(80 \%)$ definitely visit the viewpoints, and even more $(86 \%)$ said they hike (walk) in nature. The education trails are quite popular, with $57 \%$ saying they are very important and 39\% saying they are a little important. According to visitors, the most important values of this landscape are the forests (Fig. 11), followed by the viewpoints and by the special plants, lakes, peaceful landscape, and cliffs. The cultural attractions are only lagging. In another question, we asked visitors how much they agree with certain development options. Of these, the largest support was given to education trails, followed by the creation of new viewpoints. Compared to these, the development of a new camp, a new visitor centre, and an adventure park enjoy much less support.

The awareness of local products is relatively low, as only one-third (32\%) of visitors could mention any of them. The most important of these are honey, various dairy products, and Serbian brandy.

Both locals and visitors were asked if they knew the term "geotourism". Only a small number of locals (19\%) answered yes, and even relatively few of those who answered

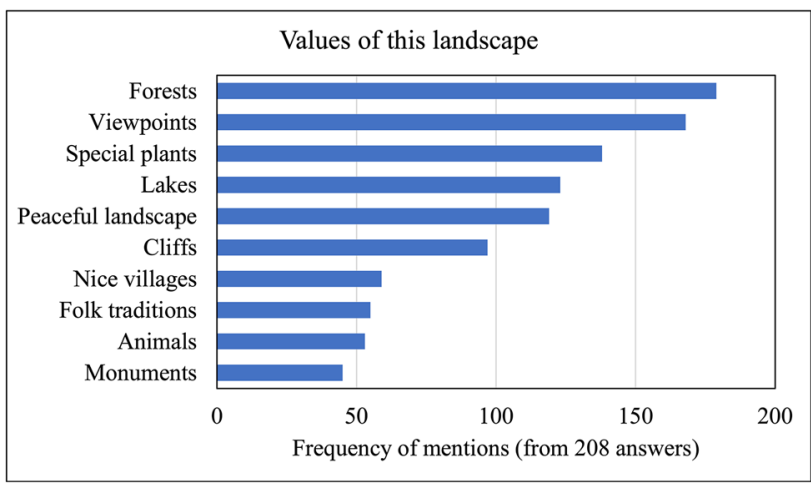

Fig. 11 Values of this landscape according to visitors yes were able to determine what this term meant (18\% gave an essentially correct answer, $40 \%$ gave a partially correct answer). In comparison, this concept is more widely known among visitors: $49 \%$ said they were familiar with the concept of "geotourism" and 32\% of those who answered yes gave a correct definition, $54 \%$ a partially correct definition to the meaning of the word "geotourism".

Visitors were also asked if they knew the meaning of the word "karst". A high share answered yes (69\%), and of those who answered yes, $10 \%$ gave a perfect definition, $26 \%$ a largely correct description, $24 \%$ a partially correct answer, and 39\% only a very general answer (e.g. "rocky" or "bare" area). We note that in the Slavic languages, the original meaning of the word "karst" has the simple meaning of "rocky" or "bare" area. We were also curious about the importance of karst areas as tourist destinations, so we asked if they had visited other karst areas in Serbia or in other countries. Forty-four percent of respondents have already visited another karst within Serbia, and almost twothirds of this group (63\%) even named exactly what other karst regions in Serbia. Twenty-seven percent of those who responded yes gave an overly general answer (e.g. in eastern Serbia), and finally, $10 \%$ named an area that is not karst. Visits to foreign karst areas were reported by $32 \%$ of respondents, and $30 \%$ of them named a karst area (e.g. Postojna) quite precisely, $65 \%$ formulated it too generally, and only 5\% mentioned a destination that is not karst.

\section{Actual (Geo)tourism Hotspots and Their Potential Role in Geoeducation}

Within the Tara NP, nature-based tourism mainly means hiking. The most important destinations are the viewpoints (Banjska Stena, Sokolarica, Bilješka Stena, Crnjeskovo, Janjač, Osluša, Ravna Stena) which are accessible within the already existing, relatively dense network of hiking trails. These provide a panoramic view from the edge of karst plateaus towards the gorge valleys (mainly Drina), thus offering visitors a "geomorphology"-based experience. The main starting point for these roads is Mitrovac. There are also information boards along the paths starting from here, which present varied but mostly biological topics. However, there are good opportunities along these paths to present the karst landforms, too.

There are also smaller exhibitions in two visitor centres: one at the above-mentioned centre in Mitrovac and the other at the NP headquarters in Bajina Bašta, which is outside the actual territory of the NP. In addition to biological values, geological/geomorphological presentation is also emphasised in these visitor centres. However, most of the tourists visiting the NP do not get to the exhibition in Bajina Bašta. Next to Bajina Bašta, there is the famous "Hut on the Drina" (Fig. 12), which is both a cultural and geologic point of 


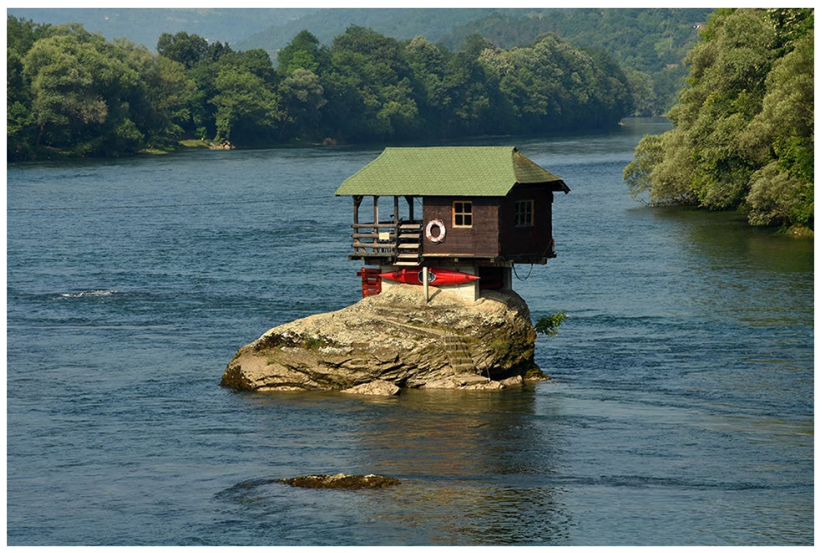

Fig. 12 Hut on the Drina River, a famous photo site near Bajina Bašta (photo by Telbisz). The rock bearing the house is also a trace of differential erosion

interest. The hut is built on a Palaeozoic meta-sandstone rock protruding from the river; thus, it represents a different era and lithology than the rocks in the nearby Tara Mountain. In connection with the Hut, it would be possible to provide information to visitors about river erosion, differential erosion, and rock formation, as it is an extremely popular site.

At present, organized canyoning tours reach a relatively small number of people, although, in addition to the "adventure" content, there would certainly be an opportunity to demonstrate a "disguised" geo-education content during canyoning, present for example the role of erosion in valley formation, erosional morphology, the exposed rock layers, the relationship between biological and geological factors in connection with drifted tree trunks. Naturally, this would require some degree of professional training of gorge tour guides. In addition, as all canyons are inside the core zone, visiting can be done only in a controlled way and carrying capacity should be defined.

Many people are attracted by the springs Vrelo and Ladjevac at the foot of Tara Mountain. They are located in easily accessible places, especially Vrelo, thus creating an opportunity to demonstrate some hydrogeological contents to a wider tourist audience. The artificial reservoirs (Perućac, Zaovine) are also a significant attraction (fishing, nice landscape, swimming), next to which the construction of cottages has already started (in the case of Perućac, "pier houses" are also present). However, due to the effective operation of the hydropower plant, there may be significant water level fluctuations; thus, there is a zone around the reservoir, where edifices should not be built. Further on, we note that the reservoir was created here well before it became part of the NP. In 2019, landslides occurred next to the Zaovine reservoir because of the artificial water level fluctuations, and some illegally built houses were damaged due to this event. It highlights how the lack of knowledge about geologic processes (and the breaking of rules) can lead to material damages. Briefly, these locations provide an excellent opportunity to present the opportunities, advantages, and disadvantages of using hydrogeological resources and the related natural hazards.

Due to limited paper length, it is not possible to present other, non-geotourism destinations here, but we also skim through them in the Discussion.

\section{Discussion}

Globally, the idea is growing that NPs, and protected areas in general, should play a role in the regional development of local communities in addition to biological and geological conservation, education, and scientific research (Mose 2007). According to our current survey, visitors to the Tara NP did not express this need. On the contrary, the local residents clearly articulated this view, and they expect the NP to provide support in the field of infrastructure development and tourism development. This support for the future development of tourism can be explained by the limited employment opportunities in other sectors of the local economy (Brankov et al. 2019).

Our survey confirms that in the case of Tara NP, biological values are considered more important by both visitors and locals than geological values. However, the latter is very important. Karsts are important to a significant part of the visitors (among whom, there is a remarkably high proportion of highly educated people in the present survey), and they also have an idea about geotourism. The survey also emphasizes some possible points of development. Namely, the construction of new education trails should be one goal as it is overwhelmingly supported by visitors. The same is true for the viewpoints. This would be especially important for returning visitors as they would be able to see positive changes in the tourism development of their favourite destination. The majority of the local population is also committed to the development of tourism, and they specifically expect the NP to take part in this. All these goals can be achieved if more emphasis is placed on the presentation of geotourism and geo-heritage during the developments.

Starting from the above reasons, we present some draft proposals for creating new education paths, as well as some technical recommendations.

\section{Suggestions to Create New Thematic Paths}

The new education paths suggested here are planned to present the diversity of geoheritage of Tara NP. They are organized around four thematic issues (for locations, see Fig. 5). The first is to show various karst landforms, the 
second presents the transition from carbonate platforms to mid-ocean remnant rocks, the third provides an introduction to the hydrology of karst, while the fourth discusses humans-karst relations. We do not provide all technical details here about the planned paths. However, we present the location of the paths and the "story" of each path. In general, we would use the already existing hiking path network.

The story of the first path is "how the surface karst landforms are created". The location is the area between Mitrovac and Banjska Stena (Fig. 5:1). This terrain allows the presentation of smaller and larger sinkholes to visitors. They can learn about how dissolution creates these landforms. Visitors can observe the arrangement of dolines along valleys and learn about the transformation of fluvial valleys into dry karst valleys. Along the path, they can see karren and understand the formation of these smaller-scale karst features. At the end of the path, at Banjska Stena viewpoint, they can see the undissected karst plateau edges and the fluvially dissected topography on the other side of the Drina River. Thus, it is a good location to teach them about the differences between fluvially formed landscapes and karst landscapes.

The story of the second path is "how the rocks are formed at the bottom of seas and oceans". The location is the area between Platno viewpoint and Duga Kosa (Fig. 5:2). It is selected for this purpose because the Triassic limestones, the Jurassic silicate sediments, and Jurassic ophiolite rocks are close to each other in this area, and even these rock units are reflected in the morphology of the landscape (Fig. 13). Moreover, the viewpoint from Platno (which is just under construction now) provides a panoramic view over the hilly Palaeozoic terrains north of it. In addition, on the small plateau area, there are some drystone wall remnants as well to learn about the human factor of living on karst. Rock outcrops can be studied in the roadcuts. And geotourists can learn about the formation of the oceanic crust, the formation of different oceanic sediments, and finally about how all of these materials are transformed and moved over continental terrains.

The story of the third path is "rivers from source to mouth and more". The location is the 365-m-long Vrelo River near Perućac (Fig. 5:3). There are lots of hydrologically or culturally interesting points that could be presented here in a relatively small area. First, the spring itself, which is the highest discharge spring in the area. People can learn about from where this water comes from, and why karst waters are so vulnerable. There is also a small trout farm next to the spring, where water quality questions could be addressed and also the human usage of a karst resource. At the mouth, where there is a waterfall, the formation of travertine can be presented. As we are now at Drina River, it can be also presented to the visitors. The river terraces, which can be seen to the east, can help to demonstrate fluvial landscape evolution. On the other hand, the Perućac dam to the west provides an opportunity to talk about human-nature relations, namely, the advantages and disadvantages of hydroelectric power stations. Finally, the nearby necropolis adds a cultural stop to this path, but it is also partly geological if the origin of tombstones is considered.

The story of the fourth path is "life in a village surrounded by karst gorges". The location is Jagoštica village (Fig. 5:4). It is really a dead-end village as the 1000-m-deep Drina Gorge prevents traffic from three sides. Along this path, visitors can learn about the human factor: see the humaninduced landscape pattern, the small patches of land that are cultivated, the orchards, the meadows, the honeycombs (which produce one of the best-known NP product). With the help of info boards (or meeting with local people), they can get acquainted with how life worked here a century ago, 50 years ago and now. They can observe signs of depopulation (which is a rather frequent phenomenon in dead-end mountain settlements), but also they can be informed about the potential use of ecotourism or geotourism. The other part of the path is more about geology: along the path, they can again observe the difference between the Jurassic silicate
Fig. 13 Morphology and geology are closely related at the planned Platno - Duga Kosa thematic path location. By following this path, visitors can view or touch rocks from the Palaeozoic to the Jurassic ophiolites. They can imagine different environments of rock formation. In addition, the morphology helps to understand the relationship of rock type and erosion

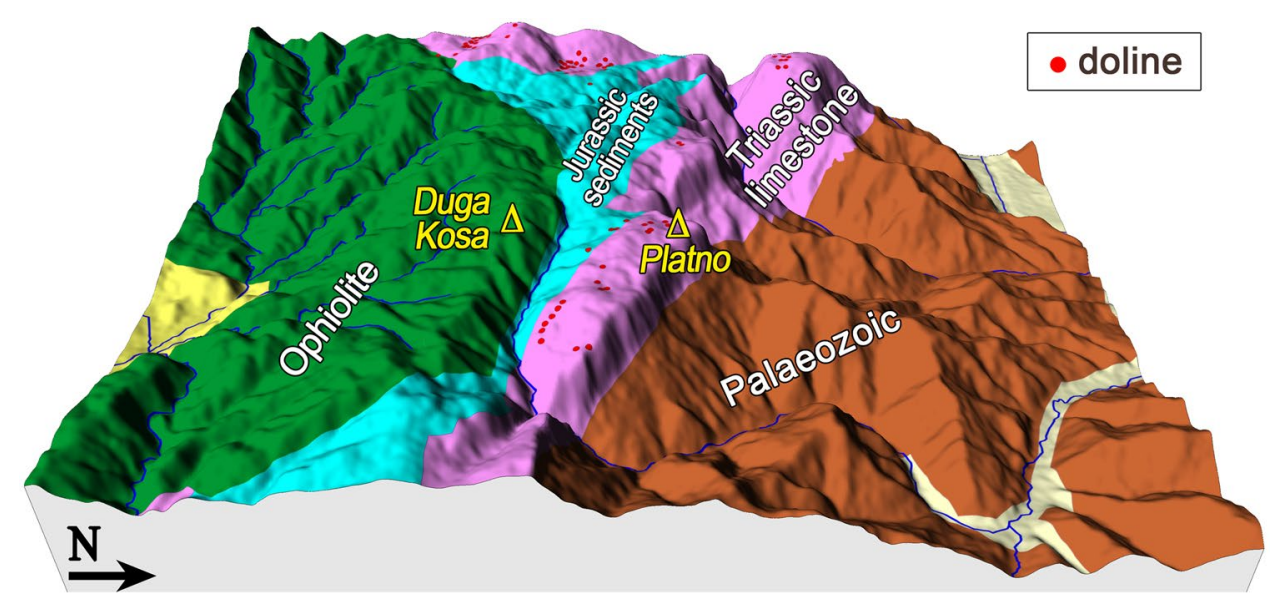


complex and the Triassic limestone. And finally, the path would lead to the nicest viewpoints over the magnificent Drina Gorge, where visitors can learn about the formation and morphology of limestone gorges.

\section{Technical Suggestions}

In order to have better access to geoheritage sites, it would be worthwhile to develop the road network and build asphalt roads in some places instead of the current macadam roads. This need was also strongly expressed by the local residents and it would be necessary primarily to approach Jagoštica in the far western part of the NP. In the absence of this, the already ongoing depopulation of the settlement is expected to accelerate. Nonetheless, with the construction of the road, geotourism can also get new destinations. According to the information received from the NP, these infrastructural developments have already started. It is important that, along with the construction of roads, there is a regulation that minimizes the increase in environmental impact. So, there should be adequate parking, waste collection facilities, and suitable speed limits on these roads. Also, environmentally friendly modes of transport on these future geotourism routes should be encouraged (the use of cycling, public transport lines, tourist trains, etc.).

It is also possible to create additional viewpoints, especially around Jagoštica, where viewpoints over the Drina Gorge and the path connecting them should be developed. The nature-friendly design of the viewpoints is recommended, so it is not necessary to build a tower, because it may be enough to make a clearing. Here could be great places to showcase the formation and evolution of large-size karst gorges. On the other hand, much of Zvijezda Mountain, located at the north-western tip of the NP, may remain a more secluded area, where biological values are more protected, and only separated groups could enter here with a guide.

Among the gorges, Rača could be made passable by placing some ladders, and thus, a circular tour could be formed in this part, while the geological knowledge of the visitors could be expanded through the presentation of the erosion forms and exposed rocks of the gorge. The NP may also retain the option to restrict access to the gorge or allow it only with a guide.

Exploring the other gorges is subject to permissions and is more of an adventure tour. However, the guides of the gorge tours could receive geological training in short courses organized by the NP, so the geo-content of the gorge tours could be enriched. The same goes for other guided tours. The members of local communities should be given priority in these trainings and the selection of tour guides so that geotourism can also serve their interests.

\section{Connect Tara NP to Neighbouring Geo-attractions and Cultural Points}

The geotouristic offer of Tara NP can and should be supplemented with other elements in two ways. The first is to add geological attractions from the wider surroundings. The Stopića Pećina and Potpećka Pećina caves can definitely be included in the geotourism offer. They are not too far away (within $70 \mathrm{~km}$ ) and already operate as show caves. It is important because there is no cave to visit in the Tara NP, although it is a karst area, so they would be an important addition to Tara's geotourism offer. But there are also caves in the vicinity of Valjevo at a similar distance, whose geotourism possibilities were studied by Antić et al. (2020b). Also, at this distance, but in the neighbouring country of Bosnia and Herzegovina, there are the bauxite mines around Palež, which include both active and inactive mines. At these sites, karst bauxite formation, mining technology, and rehabilitation opportunities could be presented. In addition, from Bosnia-Herzegovina, it is possible to see the other (Serbian) side of the Drina Gorge (Fig. 8).

An initiative has been launched, although it is still in its initial phase, aiming to create a geopark on the Serbian side called "Stari Vlah Geopark". It would cover the territory of nine municipalities in Serbia (Bajina Bašta, Užice, Čajetina, Priboj, Nova Varoš, Ivanjica, Prijepolje, Arilje, and Sjenica; Public Enterprise Tara National Park 2017). This would enable the connection of geoheritage sites in Tara NP with objects of the same type in other protected areas on the wider territory (Stopića Pećina Cave in Zlatibor Nature Park, Ušački cave system in Uvac Special Nature Reserve, Mileševka River Gorge in the eponymous Special Nature Reserve, Waterfalls of Sopotnica Natural Monument, etc.).

As our survey showed, a significant proportion of visitors have some interest in karst and geological values in general. However, pure (or dedicated) geotourists (in the meaning of Hose 2008) are presumably in the minority here as well, so if we want to attract other tourists, it is not enough to make "pure geotourism packages" but complex packages with cultural and geological sights elaborated together. Fortunately, there are plenty of opportunities for this in the vicinity of Tara NP, and some of them can be directly linked to the geoheritage. Since the subject is beyond the scope of this article, we only shortly list these sites now. The Rača Monastery is an important architectural, historical, and religious site, but more than this, the limestone tuff building stones that form the wall of the church building could provide a natural connection to the geoheritage. In addition, the role of nearby springs in the life of the monastery could also join cultural attraction to hydrogeology. The limestone material of the sarcophagi observed in the necropolises of Perućac and Rastište is also a point of connection to geology that could be brought to the attention of visitors. The Mokra 
Gora train is not only an entertainment program, but it is also an industrial monument, in connection with which we can also learn about the characteristics of former and present land use.

\section{Conclusions}

Tara NP is a protected area where the primary role is played by the preservation of biological values, and forestry plays a key role in the NP's budget. However, all this does not contradict the presentation of the geoheritage at all. The organizational framework provided by the NP can be used to more strongly present the geoheritage in and around the NP. Our surveys with local residents and visitors have pointed out two important issues. One is that local residents unambiguously support the further development of tourism, and they expect the help of the NP in this issue. However, geotourism is a rather new concept for them. On the other hand, a significant part of visitors are familiar with geotourism and they are open to development related to it. It is important to note that among the development perspectives, visitors prefer to support those that involve only minor changes in terms of the environment (e.g., new viewpoints, education trails). Naturally, the NP also tends to agree with this direction. When geotourism development is the goal, sustainability and local participation should also be in the mind (Tomićević et al. 2010; Kostić et al. 2018). A significant proportion of the local population is linked to the NP through forestry, but a third of them are directly involved in tourism. The development of geotourism may bring new opportunities for them (e.g., becoming a guide), but some additional infrastructural developments (asphalting of roads) may also contribute to the survival of these communities.

In addition, an important message from the COVID epidemic is that sites based on domestic visitors are less vulnerable. This is a favourable situation for Tara NP, as its tourism is largely based on domestic visitors.

The two suggested directions of geotourism developments, i.e. including the geoheritage of a wider area, and the creation of complex packages connected with cultural attractions can also be a useful approach for other protected areas with similar settings.

Acknowledgements The authors thank Ana Mladenović for her helpful comments on the geology of the study area.

Funding Open access funding provided by Eötvös Loránd University. This research has been supported by the National Research, Development and Innovation Office Hungary (NKFIH) K124497 project and by the Ministry of Education, Science and Technological Development of the Republic of Serbia.

Availability of Data and Material Not applicable.
Code Availability Not applicable.

\section{Declarations}

Competing Interests The authors declare no competing interests.

Open Access This article is licensed under a Creative Commons Attribution 4.0 International License, which permits use, sharing, adaptation, distribution and reproduction in any medium or format, as long as you give appropriate credit to the original author(s) and the source, provide a link to the Creative Commons licence, and indicate if changes were made. The images or other third party material in this article are included in the article's Creative Commons licence, unless indicated otherwise in a credit line to the material. If material is not included in the article's Creative Commons licence and your intended use is not permitted by statutory regulation or exceeds the permitted use, you will need to obtain permission directly from the copyright holder. To view a copy of this licence, visit http://creativecommons.org/licenses/by/4.0/.

\section{References}

Allan M, Dowling RK, Sanders D (2015) The motivations for visiting geosites: the case of Crystal Cave, Western Australia. GeoJournal of Tourism and Geosites 16(2):141-152

Antić A Tomić N, Marković S (2020a) Karst-based geotourism in Eastern Carpathian Serbia: exploration and evaluation of natural stone bridges. Geoconservation Research

Antić A, Tomić N, Djordjević T, Radulović M, Djordjević I (2020b) Speleological objects becoming show caves: evidence from the Valjevo karst area in Western Serbia. Geoheritage 12(4):1-12

Arany I, Aszalós R, Kuslits B, Tanács E (2018) Ecosystem services in protected karst areas. Interreg Danube Transnational Programme, ECO KARST project. http://www.interreg-danube.eu/uploads/ media/approved_project_output/0001/21/6fa4681195937ba917ef 3137dcfaa4431498df71.pdf. Accessed 5 Oct 2021

Blagojević I (2012) Sustainable Landscape Management in Tara National Park (Village Jagoštica, Serbia). Geographica Pannonica 16:94-102. https://doi.org/10.5937/GeoPan1203094B

Bočić N, Pahernik M, Mihevc A (2015) Geomorphological significance of the paleodrainage network on a karst plateau: the Una-Korana plateau, Dinaric karst, Croatia. Geomorphology 247:55-65. https://doi.org/10.1016/j.geomorph.2015.01.028

Bosco F (2016) 180 grotte per raccontare il fenomeno carsico in Serbia. Società di Studi Carsici “A.F. Lindner”, Ronchi dei Legionari

Božić S, Tomić N (2015) Canyons and gorges as potential geotourism destinations in Serbia: comparative analysis from two perspectives-general geotourists' and pure geotourists'. Open Geosciences 7(1):531-546. https://doi.org/10.1515/geo-2015-0040

Brankov J, Jojić Glavonjić T, Milanović Pešić A, Petrović MD, Tretiakova TN (2019) Residents' perceptions of tourism impact on community in National Parks in Serbia. European Countryside 11:124-142. https://doi.org/10.2478/euco-2019-0008

Brilha J (2002) Geoconservation and protected areas. Environ Conserv 29:273-276

Brown EM, Olson LT, Farrelly MC, Nonnemaker JM, Battles H, Hampton J (2018) Comparing response rates, costs, and tobaccorelated outcomes across phone, mail, and online surveys. Survey Practice 11(2):4406. https://doi.org/10.29115/SP-2018-0029

Ćalić J (2011) Karstic uvala revisited: toward a redefinition of the term. Geomorphology 134(1-2):32-42. https://doi.org/10.1016/j.geomo rph.2011.06.029 
Channell JET, Kozur HW (1997) How many oceans? Meliata, Vardar and Pindos oceans in Mesozoic Alpine paleogeography. Geology 25(2):183-186. https://doi.org/10.1130/0091-7613

Chiari M, Djerić N, Garfagnoli F, Hrvatović H, Krstić M, Levi N, Malasoma A, Marroni M, Menna F, Nirta G, Pandolfi L, Principi G, Saccani E, Stojadinović U, Trivić B (2011) The geology of the Zlatibor-Maljen area (Western Serbia): a geotraverse across the ophiolites of the Dinaric-Hellenic collisional belt. Ofioliti 36(2):139-166

Crofts R (2018) Putting geoheritage conservation on all agendas. Geoheritage 10:231-238. https://doi.org/10.1007/s12371-017-0239-y

Ćurčić S, Vrbica M, Vesović N, Antić D, Petković M, Bosco F, Ćurčić B (2015) A new troglobitic species of the genus Pholeuonopsis (Coleoptera: Leiodidae: Cholevinae: Leptodirini) from western Serbia, with a key to the species from Serbia. Zootaxa 3937(2):393-400. https://doi.org/10.11646/zootaxa.3937.2.10

Cvetković V, Prelević D, Schmid S (2016) Geology of South-Eastern Europe. In: Papić P (ed) Mineral and thermal waters of Southeastern Europe. Environmental Earth Sciences. Springer, Cham. https://doi.org/10.1007/978-3-319-25379-4_1

Cvetković V, Šarić K, Mladenović A (2019) Magmatizam i metamorfizam: Geohemijsko-geodinamička perspektiva (Magmatism and metamorphism: geochemical-geodynamical perspective; in Serbian). University in Belgrade, Faculty of Mining and Geology, University Goce Delčev, Štip (North Macedonia)

Ford DC, Williams PW (1989) Karst Geomorphology and Hidrology. Unwin Hyman, London

Gordon JE, Crofts R, Díaz-Martínez E, Woo KS (2018) Enhancing the role of geoconservation in protected area management and nature conservation. Geoheritage 10:191-203. https://doi.org/10.1007/ s12371-017-0240-5

Hevesi A (2000) About the Formation of Limestone Gorges. Acta Geographica Croatica 35:57-66

Hose TA (2008) Towards a history of geotourism: Definitions, antecedents and the future. Geol Soc Lond Spec Publ 300(1):37-60. https://doi.org/10.1144/SP300.5

Jemcov IR, Mladenović AS (2017) An impact of tectonic structures on the groundwater circulation and losses from surface accumulation in the area of the left bank of Lazići dam on the Tara MTS. Tehnika 72(3):357-363. https://doi.org/10.5937/tehnika1703357J (in Serbian with English abstract)

Jurković I, Palinkaš L, Garašić V, Strmić Palinkaš S (2012) Genesis of vein-stockwork cryptocrystalline magnesite from the Dinaride ophiolites. Ofioliti 37(1):13-26

Kim SS, Kim M, Park J, Guo Y (2008) Cave tourism: Tourists' characteristics, motivations to visit, and the segmentation of their behavior. Asia Pac J Tour Res 13(3):299-318. https://doi.org/10. 1080/10941660802280448

Kostić M, Lakićević M, Milićević S (2018) Sustainable tourism development of mountain tourism destinations in Serbia. Econ Agric 65:843-857. https://doi.org/10.5937/ekoPolj1802843K

Kovačević-Majkić J (2006) Kvalitet i zaštita voda na Tari kao uslov za razvoj eko-turizma (Quality and water protection on Tara Mountain as a condition for eco-tourism development). Proceedings of the Conference "Touristic valorisation of the Tara Mountain", Geographical Institute "Jovan Cvijić", SANU, Belgrade, 121-126 (in Serbian with English abstract)

Maran Stevanović A (2015) Methodological guidelines for geoheritage site assessment: a proposal from Serbia. Annales Géologiques De La Péninsule Balkanique 76:105-113

Marković J, Bočić N, Pahernik M (2016) Prostorni raspored i gustoća ponikava jugoistočnog Velebita (Spatial distribution and density of dolines in the southeastern Velebit area). Geoadria 21(1):1-28. https://doi.org/10.15291/geoadria.23

Milić C (1980) Planina Tara - primer kvantifikacije kraškog procesa (La montagne de Tara - une example de quantification du processus karstique; in Serbian, with French Summary). J Geogr Inst "Jovan Cvijić" SASA 32:87-114

Mojsilović S, Baklajić D, Djoković I (1978) Basic geological map 1:100,000, sheet Titovo Užice. Federal Geological Survey SFRJ

Mose I (ed) (2007) Protected Areas and Regional Development in Europe: Towards a New Model for the 21st Century. Ashgate Publishing, Aldershot

Nestorová Dická J, Gessert A, Bryndzová L, Telbisz T (2020) Behavioural Survey of Local Inhabitants' Views and Attitudes about Slovak Karst National Park in Slovakia. Sustainability 12(23):10029. https://doi.org/10.3390/su122310029

Official gazette SRS 5/68 (1968) Uredba o klasifikaciji voda (Regulation on classification of water; in Serbian). https://www.pravnoinformacioni-sistem.rs/SlGlasnikPortal/eli/rep/sgsrs/vlada/uredba/1968/5/2/reg. Accessed 5 Oct 2021

Olujić J, Karović J (1986) Basic geological map 1:100,000, sheet Višegrad. Federal Geological Survey SFRJ

Ouimet WB, Whipple KX, Crosby BT, Johnson JP, Schildgen TF (2008) Epigenetic gorges in fluvial landscapes. Earth Surf Proc Land 33(13):1993-2009. https://doi.org/10.1002/esp.1650

Öztürk MZ, Şimşek M, Şener MF, Utlu M (2018) GIS based analysis of doline density on Taurus Mountains, Turkey. Environ Earth Sci 77(14):536. https://doi.org/10.1007/s12665-018-7717-7

Pančić J (1876) Eine neue Conifere in den ostlichen Alpen. Von Dr. J. Pančić. In der furstl.-serbischen Staatsdruckerei, Belgrade

Petrovic AS, Nikolić D, Bogdanović DT, Carević I (2020) Assessment of karst geomorphosites on Kučaj and Beljanica mountains as a resource for the development of karst-based geopark. Acta Carsologica 49(2-3):197-190. https://doi.org/10.3986/ac. v49i2-3.8748

Pietrzyk-Kaszyńska A, Cent J, Grodzińska-Jurczak M, Szymańska M (2012) Factors influencing perception of protected areas -The case of Natura 2000 in Polish Carpathian communities. J Nat Conserv 20(5):284-292. https://doi.org/10.1016/j.jnc.2012.05.005

Public Enterprise Tara National Park (2017) Management Program of Tara National Park for 2017. Public Enterprise Tara National Park: Bajina Bašta, Serbia, 1-24 (in Serbian). https://www.nptara. rs/images/download/Program\%20upravljanja\%20Nacionalnim\% 20parkom\%20tara\%20za\%202017\%20godinu.pdf Accessed on 2 Mar 2021

Rabus B, Eineder M, Roth A, Bamler R (2003) The shuttle radar topography mission - a new class of digital elevation models acquired by spaceborne radar. ISPRS J Photogramm Remote Sens 57:241262. https://doi.org/10.1016/S0924-2716(02)00124-7

Radović D, Stevanović V, Marković D, Jovanović S, Dzukić G, Radović I (2005) Implementation of GIS technologies in assessment and protection of natural values of Tara national park. Arch Biol Sci 57:193-204

Ristić Vakanjac V, Stevanović Z, Maran Stevanović A, Vakanjac B, Čokorilo Ilić M (2015) An example of karst catchment delineation for prioritizing the protection of an intact natural area. Environ Earth Sci 74:7643-7653. https://doi.org/10.1007/978-3-64217435-3_44

Robertson A, Karamata S, Šarić K (2009) Overview of ophiolites and related units in the Late Paleozoic-Early Cenozoic magmatic and tectonic development of Tethys in the northern part of the Balkan region. Lithos 108(1-4):1-36. https://doi.org/10.1016/j.lithos. 2008.09.007

Schmid S, Bernoulli D, Fügenschuh B, Matenco L, Schefer S, Schuster R, Tischler M, Ustaszewski K (2008) The Alpine-CarpathianDinaride orogenic system: correlation and evolution of tectonic units. Swiss J Geosci 101:139-183. https://doi.org/10.1007/ s00015-008-1247-3

Stampfli GM (2000) Tethyan Oceans. In: Bozkurt E, Winchester JA, Piper JDA (eds) Tectonics and Magmatism in 
Turkey and the Surrounding Area. Geol Soc Lond Spec Publ 173:1-23.1-86239-064-9/00/

Stojanović DV, Ćurčić SB, Tomić MM (2014) Fauna Lepidoptera Nacionalnog Parka "Tara” (In Serbian). University of Novi Sad, Tara National Park, Fruška Gora National Park

Štrba L' (2019) Analysis of Criteria Affecting Geosite Visits by General Public: A Case of Slovak (Geo)Tourists. Geoheritage 11(2):291300. https://doi.org/10.1007/s12371-018-0283-2

Telbisz T (2001) Új megközelítések a töbör-morfológiában az Aggteleki-karszt példáján (New perspectives in doline morphology by the example of Aggtelek Karst). Földrajzi Közlemények 125(1-2):95-108 (in Hungarian with English abstract)

Telbisz T, Mari L, Kohán B, Ćalić J (2007) A szerbiai Miroč-hegység töbreinek térinformatikai és GPS-es terepi vizsgálata (GIS analysis of dolines in Miroč Mountain, Serbia, using GPS field data). Karsztfejlődés 12:71-90 (in Hungarian with English abstract)

Telbisz T, Boer Á, Csernátoni A, Imecs Z, Mari L, Zs Bottlik, Szabó O (2015) A Királyerdő karsztvidéke: morfológiai kérdések és élet a karszton (Karst of Munții Pădurea Craiului: morphology and life on karst). Karsztfejlődés 20:167-184. https://doi.org/10.17701/ 15.167-184 (in Hungarian with English abstract)

Telbisz T, Látos T, Deák M, Székely B, Zs K, Standovár T (2016) The advantage of lidar digital terrain models in doline morphometry compared to topographic map based datasets-Aggtelek karst (Hungary) as an example. Acta Carsologica 45(1):5-18. https:// doi.org/10.3986/ac.v45i1.4138

Telbisz T, Stergiou CL, Mindszenty A, Chatzipetros A (2019) Geological and Geomorphological Characteristics of Vikos Gorge and Tymphi Mountain (Northern Pindos National Park, Greece) and Karst-Related Social Processes of the Region. Acta Carsologica 48(1):29-42. https://doi.org/10.3986/ac.v48i1.6806
Telbisz T, Gruber P, Mari L, Kőszegi M, Bottlik Z, Standovár T (2020a) Geological Heritage, Geotourism and Local Development in Aggtelek National Park (NE Hungary). Geoheritage 12(1):5. https://doi.org/10.1007/s12371-020-00438-7

Telbisz T, Brankov J, Ćalić J (2020b) Topographic and lithologic controls behind mountain depopulation in Zlatibor District (Western Serbia). J Mt Sci 17(2):271-288. https://doi.org/10.1007/ s11629-019-5861-5

Tomić N, Božić S (2014) A modified geosite assessment model (M-GAM) and its application on the Lazar Canyon area (Serbia). Int J Environ Res 8(4):1041-1052

Tomić N, Antić A, Marković SB, Djordjević T, Zorn M, Valjavec MB (2019) Exploring the potential for speleotourism development in eastern Serbia. Geoheritage 11(2):359-369. https://doi.org/10. 1007/s12371-018-0288-x

Tomić N, Marković SB, Antić A, Tešić D (2020) Exploring the potential for geotourism development in the Danube Region of Serbia. Int J Geoheritage Parks 8(2):123-139. https://doi.org/10.1016/j. ijgeop.2020.05.001

Tomićević J, Shannon MA, Vuletić D (2010) Developing local capacity for participatory management of protected areas: the case of Tara National Park. Sumarski List 134(9-10):503-515

Trakolis D (2001) Perceptions, preferences, and reactions of local inhabitants in Vikos-Aoos National Park, Greece. Environ Manag 28(5):665-676. https://doi.org/10.1007/s002670010251

Zeremski M (1956) Reljef planine Tare (Relief of Tara Mt, in Serbian). Special Issues of the Serbian Geographical Society 33, Belgrade

Zgłobicki W, Baran-Zgłobicka B (2013) Geomorphological heritage as a tourist attraction A case study in Lubelskie Province, SE Poland. Geoheritage 5(2):137-149. https://doi.org/10.1007/ s12371-013-0076-6 